\title{
Weighing the Value of Vagueness: An Economic Perspective on Precision in the Law
}

\author{
Gillian K. Hadfield $\dagger$
}

Economics does not have an epistemology. Actors in an economic model know what they know by assumption. Even when there is uncertainty in the economic world, economic actors are presumed to know precisely the shape of that uncertainty. It might seem, then, that economists would have little to add to our understanding of the philosophical and psychological questions of what makes law sufficiently "defimite" to command compliance. Yet, on some reflection and with characteristic hubris, it is possible for an economist to find a contribution to make, largely by exploiting the well-worn economic framework that asks the following: How do different types of legal rules influence behavior? What are the costs and benefits of a particular legal rule or doctrine?

Applying this economic framework can shed substantial light on the questions raised by vagueness: How does the precision of law influence behavior? How does it affect the justification for the exercise of legal authority? Insight into these questions comes largely from economics' formalization of the concept of uncertainty. In this Paper I demonstrate how an economic analysis of uncertainty illuminates some of the behavioral assumptions animating vagueness doctrine. I then examine how economics facilitates a systematic exploration of the implicit balancing of costs and benefits inherent in legal decisions applying a vagueness analysis.

I

VAGUENESS AS UNCERTAINTY ABOUT THE LAW

When a law is vague, there is uncertainty about who and what will come within the law's proscription. ${ }^{1}$ Although economists have not addressed the question of vagueness per se, they have paid considerable attention to the question of how uncertainty influences people's responses to the law. For purposes of this Paper, I will assume that each person attaches a certain probability of being held liable for violating the law to a

Copyright $\odot 1994$ California Law Review, Inc.

$\dagger$ Acting Professor of Law, Boalt Hall School of Law, University of California, Berkeley. B.A.H. 1983, Queen's University; J.D 1988, Ph.D. 1990, Stanford University.

1. Laws that are enabling nonetheless by their nature leave a residual category of actions that are proscribed; consequently we lose nothing by focusing on laws as prohibitions. 
given behavior or activity. A law, from an individual's point of view, represents the compilation of that individual's assessment of the probabilities of being held liable for a range of different behaviors or activities into a (subjective) probability function. If a law is perfectly certain, these probabilities are all one or zero: an individual knows with certainty which actions will and which actions will not incur liability. In practice, these probabilities might range between one and zero for numerous reasons, including imperfect enforcement (not all violators are caught or convicted), mistakes in the determination of factual issues, and errors in the identification of the applicable legal rule. ${ }^{2}$

The type of uncertainty raised by the doctrine of vagueness, however, is not about the application of law in practice but about the applicability of law in theory. If we assume away the practical obstacles to certainty of application in law, then probabilities of liability will differ from one or zero only because the law itself is not clear about whether a particular action by a particular individual is prohibited. Alternatively, the resolution of actual liability when a law is uncertain or vague is determined not solely by the law but also by the discretion of actors in the legal system, such as police officers, prosecutors, regulators, and courts. This dependence of actual liability on official discretion is what links the two most commonly articulated normative principles behind the vagueness doctrine: fair notice and control of arbitrary enforcement. ${ }^{3}$ Because the very content of law depends not only on its text but also on the discretion of officials in the legal system, even an individual who knows the text of the law, as all are held to do, must in the end assign probabilities other than zero or one to her actions. When the exercise of such discretion cannot be predicted with any degree of certainty, lack of notice and arbitrary enforcement concerns coincide.

We can imagine a case in which these two concerns diverge in theory; such a case sheds light on the role that vagueness doctrine plays in constitutional law in practice. Suppose the exercise of discretion can be predicted perfectly-blacks know with certainty, for example, that if they stand on the corner in a group for more than ten minutes they will be arrested for loitering, while whites know with certainty that if they do the same they will not be arrested. Such a law poses no problem of fair notice. The problem of arbitrary enforcement is so severe, though, that the law violates the constitutional mandate of equal protection. Thus, in theory, fair notice and arbitrary enforcement concerns diverge. In practice, however, plaintiffs will have a hard time proving that the exercise of official discretion is perfectly predictable and thus a hard time proving the law unconstitutional on

2. An individual's assessment of these probabilities depends on these factors directly, as well as on the citizen's awareness of the presence of these factors.

3. See, e.g., Kolender v. Lawson, 461 U.S. 352, 357 (1983) (requiring that the statute define the proscribed conduct "with sufficient definiteness that ordinary people can understand what conduct is prohibited and in a manner that does not encourage arbitrary and discriminatory enforcement"). 
equal protection grounds. ${ }^{4}$ Plaintiffs who wish to challenge the law will instead be well-advised to contend that the law is unconstitutional on vagueness grounds - that it is impermissibly vague because the exercise of discretion makes the law both unpredictable and open to abuse. Thus, for practical purposes, the case raising vagueness rather than other substantive constitutional claims can be understood to exhibit a convergence of fair notice and arbitrary enforcement concerns created by the dependence of the content of the challenged law on the uncertain (and hence potentially discriminatory) exercise of discretion.

\section{II \\ Behavioral Consequences of Vagueness}

Having set out an interpretation of vagueness as uncertainty about the content of law arising from official discretion, I want to begin the economic analysis of vagueness by considering the impact of vagueness on law's behavioral consequences.

At a basic level, the void-for-vagueness doctrine is concerned with how uncertainty about the content of substantive law influences the behavior of those to whom laws are addressed. The "fair warning" notion identified by the courts as an animating principle of the doctrine thus seeks to ensure that individuals know the bounds of legal activity and can adjust their behavior to these bounds. Here economists have a significant contribution to make, for although they have not addressed the problem of vagueness in its constitutional dimension, they have given considerable attention to how uncertainty about law influences the response to law. For these

4. But see Yick Wo v. Hopkins, 118 U.S. 356 (1886). The Court was concerned with the degree of discretion vested in the local government, id. at 366-67-a concern that today might lead to invalidation of the ordinance on grounds of vagueness. However, rather than declare the ordinance unconstitutional, the Court ordered the imprisoned Chinese laundrymen to be freed. It relied on the actual discriminatory application of the ordimance, stating:

In the present cases we are not obliged to reason from the probable to the actual, and pass upon the validity of the ordinances complained of, as tried merely by the opportunities which their terms afford, of unequal and unjust discrimination in their administration. For the cases present the ordinances in actual operation, and the facts shown establish an administration directed so exclusively against a particular class of persons as to warrant and require the conclusion, that, whatever may have been the intent of the ordmances as adopted, they are applied by the public authorities charged with their administration, and thus representing the State itself, with a mind so unequal and oppressive as to amount to a practical denial by the State of that equal protection of the laws which is secured to the petitioners, as to all other persons, by the broad and benign provisions of the Fourteenth Amendment to the Constitution of the United States. Though the law itself be fair on its face and impartial in appearance, yet, if it is applied and administered by public authority with an evil eye and an unequal hand, so as practically to make unjust and illegal discriminations between persons in similar circumstances, material to their rights, the denial of equal justice is still within the prohibition of the Constitution.

Id. at 373-74. 
purposes it does not matter what the source of uncertainty is, except in one sense that I will explore shortly. ${ }^{5}$

The deterrence literature in law and economics has explored how uncertain legal standards influence compliance with the law. Traditionally, scholars employing economic analysis have concluded that uncertainty will lead to undercompliance because people will discount the magnitude of punishment for illegal acts by the probabihty of being caught. Richard Craswell and John Calfee, however, have pointed out that the probability of being caught and convicted is itself a function of the level of compliance with the law. ${ }^{6}$ They have demonstrated that there is a tendency to overcomply with the law when uncertainty is not too broad, or when damages are multiplied by the inverse of the probability of punishment in an attempt to compensate for the traditionally recognized underdeterrence effect of imperfect enforcement. ${ }^{7}$ An individual, uncertain about the legal standard, knows that there is a chance that she will be held liable even when she adopts a socially optimal level of behavior. The decrease in probability of being held liable gained by overcompliance may be substantial enough to offset the personal cost of overcompliance; it can therefore make sense for an individual to overcomply in order to reduce expected damages. ${ }^{8}$ This is the benefit of a safe harbor, for example, even if the safe harbor is more than is required by the courts on average.

Craswell and Calfee's analysis can be used to give a concrete economic explanation to the correspondence noted by Anthony Amsterdam between the Supreme Court's use of the vagueness doctrine and the likelihood that a purportedly vague statute encroaches on constitutionally protected rights. ${ }^{9}$ Even if a legal rule on average reaches only behavior within the power of a state to prohibit (post-viability abortions or mutilation of the flag, for example), uncertainty about the rule's content can cause individuals to protect themselves by overcomplying, that is, foregoing behavior in which they have a right to engage (pre-viability abortions, or expressive flag burning, for example). Amsterdam suggests that the Court's use of the vagueness doctrine to create "buffer zones"10 around Bill of Rights freedoms is in some sense surreptitious, or at least a departure from the underlying principles of the vagueness doctrine. He argues, for example, that the doctrine allows federal courts to review vague state laws that occasion con-

5. See infra note 30 and accompanying text (discussing the cost of determining the content of law when law is uncertain due to vagueness).

6. Richard Craswell \& John E. Calfee, Deterrence and Uncertain Legal Standards, 2 J.L. EcoN. \& Organization 279, 281 (1986).

7. Id. at 280 .

8. Id. at 282. These results hold even though the parties are risk-neutral (the result is stronger if the parties are risk-averse) and even though the standard applied by the court is on avcrage at the optimal level.

9. See Anthony G. Amsterdam, Note, The Void-For-Vagueness Doctrine in the Supreme Court,

109 U. PA. L. REv. 67, 75 (1960).

10. Id. at 75,85 . 
stitutional violations that would themselves be unreviewable because of procedural obstacles such as lack of standing, limitations on the scope of review, or restrictions on the scope of the court's remedial powers. ${ }^{11}$

An economic analysis of uncertainty suggests, however, that the Supreme Court's actions can in fact be understood as an appropriate response to overdeterrence caused by vague legal rules that fail to give adequate notice of precisely what is proscribed. This response would continue to be appropriate even in the absence of procedural constraints on federal review. The fact that the Court creates buffer zones around the exercise of constitutional rights but not other lawful behavior may speak to the implicit calculus that only vagueness that chills constitutionally-protected behavior is worthy of federal scrutiny and sanction. Vagueness in, for example, a criminal negligence standard that merely causes people to be extra cautious on the highway-driving less than the lawful fifty-five miles per hour to protect themselves against the uncertainties of enforcement-is hardly likely to excite a call in the Supreme Court for greater clarity in the law.

The behavioral implications of uncertain laws are in fact even richer than Craswell and Calfee's model indicates. Elsewhere, I argue that, due to their limited competence, courts and legislatures should sometimes fashion vague standards rather than bright line rules. ${ }^{12}$ That is, in some cases more uncertainty is better than less. The intuition is as follows. A bright line rule causes all individuals either to steer into the same safe harbor, even if that harbor is quite costly for some, or to ignore the rule entirely if the harbor is simply too costly. The effect of the rule is likely to be one of two extremes: either excessive compliance or nil. A vague standard, on the other hand, does not attach sharp changes in the probability liability to small changes in a particular behavior selected as the turning point for liability; rather, as behavior improves, there is a gradual reduction in the probability of liability that elicits different responses from different individuals. These responses are likely to fall between the extremes induced by the bright line rule and thus likely to more closely approach some optimal outcome. This comparison of rules and standards implies that there may be costs to encouraging legislatures to choose clearly delineated rules over vague standards when courts are likely to make mistakes in the selection of appropriate rules. Vagueness softens the impact of judicial error on individual incentives without abandoning entirely the effort to control private behavior.

11. Id. at $96-115$.

12. Gillian K. Hadfield, Judicial Competence and the Interpretation of Incomplete Contracts, 23 J. LEGAL STUD. 159 (1994). 
III

\section{Institutional Consequences of Uncertainty: The Value OF VAGUENESS}

Recognizing that vagueness niay have its benefits is iniportant to a study of the appropriate contours of vagueness doctrine in the law. The analysis of uncertainty in the context of judicial error suggests that vagueness, by iniproving the ability of limitedly conıpetent courts to control behavior optimally, nay be institutionally advantageous. Whether uncertainty arises from practical sources (like judicial error) or due to vagueness is largely uniniportant for predictions about how the uncertainty will affect private decisionmaking. The source of the uncertainty becomes relevant only when we turn to the normative question whether the legal systen should be designed to reduce uncertainty. Some level of practical uncertainty is unavoidable: even juries given precise instructions and judges subject to appellate review will sonetimes make mistakes. Thus individuals can rarely be entirely sure about the legal consequences of the behavior in which they engage. What, then, makes uncertainty about legal consequences seem an acceptable reality in practice but an impermissible deviation from "fair notice" in the case of vagueness doctrine? Perhaps it is the perception that vagueness is avoidable while some uncertainty due to practical constraints is not. But this does not adequately explain why the vagueness doctrine, despite its theoretically unlimited applicability, is nonetheless a doctrine with highly limited scope in the law. Concern about the cost of reducing uncertainty better explains the selective sanctioning of uncertainty and vagueness in the law. From an economic perspective the judgnent is that practical uncertainty is "fair" (as in "fair notice") because the cost of reducing uncertainty is prohibitive.

In the case of vagueness, because only a small subset of vague statutes are apparently "unfair," we need to assess with care the cost of reducing uncertainty. That is, we need to estabhish the value of vagueness. The fact that vagueness is fatal when its cost is deterrence of constitutionally-protected behavior but is acceptable when its cost is deterrence of other lawful behavior, like driving fifty-five miles per hour on the highway, implies that the value of vagueness is not zero. Alternatively, it implies that reducing uncertainty by requiring greater precision in the law is only worthwhile when vagueness imposes a substantial cost. Similarly, the potential for discriminatory enforcenient raises void-for-vagueness concerns when the group potentially discriminated against has a constitutionally protected status (such as race) or engages in constitutionally protected activity (such as 
speech), ${ }^{13}$ but not in a purely commercial regulatory context. ${ }^{14}$ These examples speak to an implicit weighing of the value of vagueness against the cost of vagueness in different settings. An economic analysis merely urges that we make this valuation explicit.

Thinking about the value of vagueness in the law leads us to expand our focus from the relationship between the law and the individual to the institutional roles played by vagueness and precision in the design of a legal system. Legal commentators have long recognized the role that vagueness doctrine plays in structuring the federal system. ${ }^{15}$ Economic analysis can advance the study of the doctrine's institutional role. To see how, think of legislation as a contract intended to determine the tasks the legislature will delegate to officials in the judicial system such as the police or the courts. Vagueness in a statute can be analogized to incompleteness in a contract; vague statutes, like incomplete contracts, leave some residual discretion with the relevant actors. This analogy is useful to an understanding of the institutional role of vagueness doctrine because it leads us to ask the same questions about incomplete statutes that we ask about incomplete contracts: Why are contracts (statutes) incomplete? How is the exercise of residual discretion controlled, if at all? I will consider these questions in turn.

There are several reasons why optimal (the best feasible) contracts may be incomplete, each of which can be applied to vagueness in statutes. First, completeness may be practically unattainable due to the cost of identifying all the relevant contingencies and detailing the appropriate behavior under each. Similarly, legislation may be vague because it is extremely costly to detail specific legislative mandates for a myriad of different possible applications. ${ }^{16}$ In this case, the value of vagueness is simply the saving of these costs. Second, completeness may be undesirable because uncertainty about the future makes it advisable for contracting parties to defer negotiation on some aspects of their relationship until more is known about the shape of future events. Similarly, it may be valuable to keep legislation

13. See, e.g., Kolender v. Lawson, 461 U.S. 352, 360 (1983) (holding anti-loitering law requiring persons to present "credible and reliable" identification when stopped by the police void for vagueness because it allowed for arbitrary and discriminatory enforcement against particular groups); Smith v. Goguen, 415 U.S. 566, 578 (1974) (striking down flag desecration statute on vagueness grounds because it subjected defendant to criminal liability "under a standard so indefinite that police, court, and jury were free to react to nothing more than their own preferences for treatment of the flag").

14. See, e.g., Old Dearborn Distrib. Co. v. Seagram-Distillers Corp., 299 U.S. 183, 196-97 (1936) (sustaining the validity of a fair trade statute against a vagueness challenge); Hygrade Provision Co. v. Sherman, 266 U.S. 497, 501-02 (1925) (upholding a criminal statute that punished merchants who falsely represented food as "kosher" against a void-for-vagueness challenge).

15. See Amsterdam, supra note 9, at 81, 88-96.

16. Colin S. Diver, The Optimal Precision of Administrative Rules, 93 YALE L.J. 65, 71-74 (1983), and Louis Kaplow, Rules Versus Standards: An Economic Analysis, 42 DukE L.J. 557, 579-84 (1992), have explored the relative costs of producing vague as opposed to detailed laws. 
vague so that "terms" can be filled in later by quasi-legislative processes in regulatory agencies and by the courts. ${ }^{17}$

Completeness in a contract may also be undesirable because one of the parties (the one to whom residual discretion is allocated) will be in a better position in the future, due to access to private information, to choose optimal behavior. A similar rationale for vague legislation is evident when legislation leaves the police with residual discretion on the street; in this setting any deliberative process that courts and regulators can undertake may be hampered by time and expertise constraints.

These similarities notwithstanding, there is an important difference between the contractual and statutory settings. In the contractual setting we ordinarily treat the need for adaptation to evolving circumstances as if it were the sole benefit of incompleteness. In the legislative context, however, there is also a potential value to the behavioral diversity permitted by incompleteness. To the extent that vague legislation is interpreted differently by different individuals subject to the legislation, vagueness introduces variability into their behavior. This variability may be inherently valuable from a social perspective.

Consider the following. ${ }^{18}$ Suppose a community of 100 shepherds is contemplating migration to new grazing lands and may go by either of two routes. The shepherds know that wolves will block and kill all the sheep passing on one of these routes, but it is not known on which route. Imagine that the group sends a scout to observe the wolves and predict which route will be safer; the scout determines that there is a $70 \%$ chance the wolves will be on the first route and a $30 \%$ chance they will be on the second route when the group passes. If the scout gives this precise information to the shepherds and each shepherd owns and is primarily dependent on his or her own sheep for subsistence, each will select the second route to the new location because each faces a higher chance of survival on this route. If for the society as a whole, however, the marginal value of a sheep diminishes as the total size of the flock grows, ${ }^{19}$ then it will be socially optimal for a minority of shepherds to take the high risk route and the remainder the low risk route. ${ }^{20}$ One way to accomplish this is for the scout to communicate

17. Vague laws may achieve greater "congruence" between objectives and outcomes. Divcr, supra note 16 , at $70-71$.

18. This example is a formalization of an example in Ido Erev et al., Vagueness, Ambiguity, and the Cost of Mutual Understanding, 2 Psychol. Scr. 321, 321 (1991), in which the authors argue that vague and ambiguous natural language is commonly used to serve the needs of the linguistic community.

19. This relationship could arise, for example, if there is a form of communal social insurance providing that those with surviving sheep share their resources in the event that another shepherd loses his or her sheep. A sheep then supports the subsistence of a greater number of people when sheep are scarce: it will be put to less valuable uses when sheep are plentiful. Formally, the requirement is that the social utility function be concave in the number of sheep.

20. For example, suppose the social utility function is $U=\sqrt{x}$. This implies that the expected utility function is $E U=p_{\ell} \sqrt{x_{l}}+p_{h}, \sqrt{x_{h}}$ where $p_{\ell}\left(p_{h}\right)$ is the probability that the sheep will survive on the 
the information about the risks on the different routes in a vague way that leads some shepherds to take the riskier route.

The example is intriguing because it suggests that the value to society of encouraging diversity in the behavior of individuals may also lie behind the vagueness of some legal rules. One of the consequences of vague rules about speech or commercial behavior, for example, is to permit a degree of diversity in the messages individuals communicate, the products they produce, or the means of production they employ-without completely ignoring the estimated risks of harm to society should some of the messages or products or means of production become widespread. A small degree of experimentation by individuals acting on the margin of the permissible may be deemed valuable because of uncertainty among lawmakers and regulators about what constitutes optimal behavior. ${ }^{21}$ The diversity of activities encouraged by vagueness, in turn, contributes to decisionmakers' refinement of the law. Vagueness introduces variability into the types of cases heard by courts or regulatory agencies. This variability gives these institutions more information about the nature of the activity regulated, thus improving their ability to develop law. ${ }^{22}$

There is also a potential organizational benefit in the capacity of a vague rule to produce more information about an activity that society seeks to regulate optimally. To see this, recall the analogy between legislation and contracts. An unenforceable term in a contract may be of greater value than either an enforceable term or no term at all because of the unenforceable term's ability to allow the party that performs the contract term to enhance its market reputation. ${ }^{23}$ Suppose there are two types of financial lenders, financially stable and unstable. If the financially stable lender makes an unenforceable promise to issue a future loan, it will enhance its reputation if it complies with the promise. By doing so, it demonstrates that it is financially stable and so is able to attract a higher price in the market. The financially unstable lender will be unable to reap the same benefit because its instability will make performance of the promise so costly that the lender will renege on the unenforceable promise. Were the promise enforceable, this divergence could not enierge, for both the stable and the unstable lender would (assuming effective enforcenient) perform on the promise.

low (high) risk route and $x_{f}\left(x_{h}\right)$ is the number of sheep taking the low (high) risk route. If all 100 sheep go by the low risk route, expected social utility is 7 . If 85 sheep go by the low risk route and 15 by the high risk route, social utility is 7.62 ; this is the optimal solution from a social perspective.

21. Whether a person will experiment or will be overdeterred will depend on the value the person places on engaging in the activity, the person's subjective assessment of the probability of being held liable if she engages in the activity, and the cost of the potential punishment if held liable.

22. Cf. Gillian K. Hadfield, Bias in the Evolution of Legal Rules, 80 GEo. L.J. 583, 610-11 (1992) (arguing that ambiguity aids the evolution of legal rules by mitigating biases in the sample of cases seen by courts and on which they depend for updating rules).

23. See Arnoud W.A. Boot et al., Reputation and Discretion in Financial Contracting, 83 AM. EcoN. Rev. 1165 (1993). 
We can imagine an analog in the legislation context. When those who enforce legislation (for example, agency heads, police, and prosecutors) retain discretion under a vague law, they may have an incentive to develop a reputation for the wise exercise of that discretion. (Perhaps wisely exercised discretion improves promotion prospects.) This could lead to better selection of agency administrators, police, and prosecutors, and perhaps better enforcement behavior than would be the case if the governing law laid out precisely what was required of these officials in all circumstances.

Returning to the contract analogy reveals a final aspect of the value of vagueness. Parties to a contract might leave aspects of it incomplete because they simply cannot resolve all their differences. Similarly, legislators may find that vagueness is essential to the process of building support for legislation: precisely drawn statutes may be more likely to concentrate interests, while vague statutes keep them diffuse. And as we know from public choice models of the legislative process, the likelihood of passing legislation diminishes as the forces opposed become more concentrated. ${ }^{24}$

Incompleteness in contracts and vagueness in statutes can also result not from optimal design but from strategic behavior. Contracts may be incomplete, for example, because parties do not want to reveal private information during negotiation. ${ }^{25}$ Legislators may draft vague statutes for similarly strategic reasons. Legislators may want to avoid responsibility for outcomes that excite public anger; ${ }^{26}$ vagueness facilitates their evasion of blame by allowing them to attribute bad outcomes to the resolution of vague terms by regulatory agencies or courts. ${ }^{27}$ Vagueness also allows legislators to represent the implications of legislation differently to different constituent groups and thus to satisfy a broader range of a heterogeneous population. In these contexts legislators value vagueness not as a tool in the design of socially optimal legal rules but rather as protection for their careers.

24. See, e.g., William N. Eskridge, Jr., Politics without Romance: Implications of Public Choice Theory for Statutory Interpretation, 74 VA. L. REv. 275, 289-95 (1988). Diver also notes that more transparent legal rules raise the costs of securing agreement among participants in the rule-making process because greater precision sharpens value conflicts. Diver, supra note 16, at 73 .

25. See Ian Ayres \& Robert Gertner, Filling Gaps in Incomplete Contracts: An Economic Theory of Default Rules, 99 YALE L.J. 87, 94, 127 (1989).

26. Linda R. Cohen and Roger G. Noll present a model in How to Vote, Whether to Vote: Strategies for Voting and Abstaining on Congressional Roll Calls, 13 POL. BeHAV. 97 (1991), in which legislators will always prefer to vote against legislation when they expect to be in the minority bccause (per the authors' assumption) those angered by the legislation will be more likely to learn of and punish their legislator's behavior than those benefitted by the legislation. "[L]egislators do better if they risk alienating winners rather than losers." Id. at 101.

27. The value of a vague statute in shifting blame for bad outcomes to the courts is evidenced by the Civil Rights Act of 1991 in which Congress responded to the Supreme Court's unpopular interpretation of vague provisions of Title VII of the Civil Rights Act of 1964. See Civil Rights Act of 1991, Pub. L. No. 102-166, 105 Stat. 1071. Congress, ever strategic, indicated that it was restoring the law to the meaning it held before the unpopular Supreme Court decisions without articulating what that meaning was. See id. $\S 3,105$ Stat. at 1071. 
Thinking about the source and function of incompleteness or vagueness in statutes lends itself to some straightforward observations about the optimal contours of a void-for-vagueness doctrine. If vagueness is a response to the costs of precision, it is important to assess these costs in determining whether, or more likely when, courts should tolerate vagueness in legislation. This may be implicit in current vagueness doctrine, as evidenced by its narrow application..$^{28}$ But it is likely that havimg courts pay explicit attention to the costs of precision in any particular setting would hone apphication of the doctrine in that setting. Weighing such costs raises questions of institutions' relative competence to make law and the appropriate locus for lawmaking in a democracy. ${ }^{29}$ Courts should pay attention to the costs of demanding precision of the legislature vis-á-vis the costs of having a vague statute filled in by regulators and the courts. At a minimum, to the extent that regulators and courts undertake the task of filling in the blanks themselves, they should recognize that some laws may, with good reason, operate unexpectedly (to both the legislature and the citizen) on some individuals.

There is an additional cost to vagueness that also must be weighed in order to understand the institutional impact of a void-for-vagueness doctrine. Uncertainty in the law places on those to whom the law is addressed the burden of determiming the law's content and the cost of bearing risk. These costs differ with the nature of the law and of the parties in question. ${ }^{30}$ As previously noted, the vagueness of many commercial standards is not regarded as problematic. Courts may implicitly assume that regulated commercial entities can efficiently satisfy their need to be informed about a wide range of detailed legal rules by investing in a high fixed cost/low marginal cost system of obtaining the information necessary to bring greater precision to vaguely worded legislation. For example, in-house lawyers can be put to work researching case law and other sources to give shape to the probability of liability. Also, regulated commercial entities' access to markets for liability insurance reduces the cost of bearing the risk of uncertain liability rules.

Private individuals, on the other hand, face a very high cost of determining the content of vaguely worded criminal laws. To avoid surprise about the law, one first needs to know when one does not know enough and needs to research the law; moreover, when vagueness leaves the content of law to the discretion of individual police officers, predicting how this discretion will be exercised is nearly impossible. It is much easier to make

28. See Amsterdam, supra note 9, at 72 (exploring the Court's "cavalier treatment of many a vagueness argument").

29. Fruitful analogies might include the allocation of power between judge and jury, and between agency and court.

30. Kaplow also considers how the costs of learning what the law requires vary with the precision of the law. Kaplow, supra note 16, at 571-77. 
predictions about how regulators or courts will exercise discretion, for there are at least published records of how they have exercised discretion in the past, as well as more or less public conventions about how discretion should be exercised by these actors. Moreover, markets for insurance against the risk of criminal prosecution and conviction are, to say the least, thin. Courts and legislatures should weigh the relative cost of vagueness to those to whom vague laws are addressed against the value of vagueness as a form of optimally incomplete contract.

The trickiest task may be disentangling optimal vagueness from strategic vagueness which, without reciprocal benefits, forces citizens to bear the costs of determining what the law is and creates overdeterrence. The question is whether courts can identify those cases in which strategic incentives to leave legislation vague have made a statute less certain than it would optimally be. If legislation is strategically vague, then a decision to void the statute might move the legislature toward the optimal level of uncertainty. ${ }^{31}$

The second principal issue raised by our analogy between vague statutes and incomplete contracts is the means of controlling the exercise of residual discretion. In the incomplete contracting setting, the exercise of future discretion is controlled by other incentives structured by the contract (for example, the compensation scheme) or by the market (for example, reputation). In the statutory setting, control over the exercise of discretion is found in several places. Control over the exercise of police discretion can be found in police disciplinary procedures and, to some degree, in the tort system. Control over police discretion is also the focus of legal doctrines such as the exclusionary rule. Control over regulatory and court discretion arises from the hierarchical nature of review, the requirement of articulable reasons for a particular exercise of discretion, public opinion, and the professional ambitions of regulators and judges. These control mechanisms need to be understood before we can judge the value of vagueness in a particular setting. Seen in the light of the incomplete contracting model, each of these mechanisms has substantive implications for the content of the law, the cost of determining the content of law, the residual uncertainty left in the law ("fair notice"), and the risks of arbitrary enforcement.

A void-for-vagueness doctrine is the ultimate mechanism for controlling the exercise of residual discretion in the law. We can see this particularly in the greater likelihood that federal courts will void a state statute for

31. This is a conjecture that requires substantially more careful attention from a political economy perspective. The unexplored issue is the implication of a void-for-vagueness doctrine for the strategic interaction of court and legislature or regulator and legislature. 
vagueness when state courts have not adequately filled in its gaps. ${ }^{32}$ These federalism issues routinely arise, in the Supreme Court at least, in the context of concerns about the extent to which official discretion under a vague statute will chill the exercise of constitutionally-protected behavior; thus, it is possible to interpret this aspect of the doctrine as simply permitting state courts to "save" an otherwise overreaching statute by interpreting it to specifically exclude protected activity. But from the incomplete contracting perspective, we can also interpret this aspect of the doctrine as federal monitoring of the vague statutes' implicit allocation to state courts of responsibility for the resolution of the uncertainty in the statute. This interpretation suggests that a challenge on vagueness grounds should have an element of "ripeness" to it: state courts must be given adequate opportunity to perform their role in resolving statutory uncertainty. Vagueness doctrine can then operate as a final check that state courts or regulators are carrying out the duties assigned to them under the incomplete "contract" implicit in the vague statute. Alternatively, where appropriate, judges can use a review for vagueness to question the wisdom of a particular allocation of responsibility for the resolution of uncertainty, in light of the costs of interim uncertainty, the relative competence of different bodies (although this is something on which deference is probably due), and the cost of achieving greater legislative certainty.

\section{CONCLUSTON}

An economic analysis of vagueness is worthwhile because it leads us to consider explicitly the costs and benefits of precision in legislation. The implicit consideration of the value of vagueness is already evident in the fact that only in a very limited number of cases will vagueness result in nullification of statutes. Law does not, in fact, everywhere require precision in order to command compliance in a modern legal system. Once we begin to explore this more explicitly, as I have done in sketchy fashion in this Paper, we can see how much more complex are the requirements of precision.

An economic analysis also sheds light on the inadequacy of the purported normative principles underlying the vagueness doctrine. Since the doctrine is in fact limited and since uncertainty arises from numerous sources that apparently raise the same concerns, it is inadequate to say that vagueness voids a statute because of the lack of "fair" warning and the potential for arbitrary enforcement. Practice and theory both speak to the essential and pervasive role of discretion in modern law. As the restricted applicability of the doctrine itself testifies, "fairness" reflects a number of considerations, such as the constitutionality of overdeterrence of behavior

32. See, e.g., Kolender v. Lawson, 461 U.S. 352, 358 (1983) (noting that the statute, "as presently drafted and as construed by the state courts, contains no standard for determining what a suspect has to do"). 
by uncertain legal standards. An economic analysis of vagueness makes explicit the role that vagueness plays in the design of a legal system. It may behoove the courts and legislators to take heed of the more complex underpinnings of a doctrine that sometimes, in some contexts, but not by any means always, announces that law must be sufficiently defimite to command compliance. 